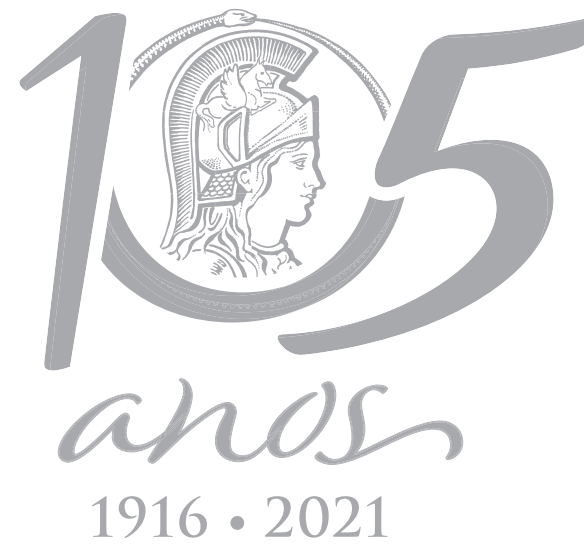

$1916 \cdot 2021$

\title{
ECOSYSTEMS
}

\section{Albinism in Artibeus planirostris (Chiroptera, Phyllostomidae) in the Caatinga biome and updated list of albino bats in Brazil}

\author{
EDSON S.B. LEAL, THAÍS C. LIRA, ANA C.L. GARCIA \& MARTÍN A. MONTES
}

\begin{abstract}
Albinism is a genetic disorder that results in a deficiency in melanin production. This type of chromatic alteration may affect several vertebrate species, but is rarely observed in nature. In Brazil, for the bat group, only 15 albino individuals have been registered. Here we present a new case for Artibeus planirostris. A pregnant female of this species with alopecia was captured in the Caatinga biome. A compilation of the distribution of albino bats in Brazil is presented.
\end{abstract}

Key words: bat, chromatic alteration, mammals, Northeastern Brazil, semi-arid zone.

\section{INTRODUCTION}

The albinism is an autosomal recessive genetic trait in vertebrates, characterized by a complete lack of melanin. This disorder occurs due to the absence of tyrosinase in the melanocytes, an enzyme essential for melanin production. Albino individuals have skin, hair or feathers white and red eyes (Hofreiter \& Schöneberg 2010).

Albinism is a rare condition in wild populations but has been recorded in approximately 60 bat species (Lucati \& LópezBaucélls 2016). Here we reported a new record of albinism for Artibeus planirostris in the Caatinga biome. An updated list with informations on albino bats collected in Brazil is also presented.

\section{MATERIALS AND METHODS}

One albino pregnant bat was collected at Fazenda Tamanduá (700'14"S/37응'38"W, Santa Terezinha, Paraíba, Brazil). This is the largest protected area of Caatinga biome, including a legal reserve of 614 hectares, and a Private
Natural Heritage Reserve of 325 hectares (ordinance 110/98-N IBAMA-PB; Neves et al. 1999).

The albino bat was collected with a mist-net $(12 \mathrm{~m} \times 3 \mathrm{~m})$ at ground level at 20:00h on October 19th, 2012 (SISBio: no115971). External and cranial measurements were taken according to Vizotto \& Taddei (1973) using a digital caliper (capacity $20 \mathrm{~cm}$, precision $0.05 \mathrm{~mm}$ ). The bat was fixed and the skull was removed according to Pacheco (2004). The specimen was deposited in the Collection of Mammals of the Federal University of Pernambuco, UFPE 3709.

\section{RESULTS AND DISCUSSION}

The albino individual (Figure 1) was identified as Artibeus planirostris (Spix, 1823) by the following external and cranial characteristics: horseshoe of nose leaf free mediobasally, dorsal fur short, warts arranged in front of lower lip, wide post orbital constriction (greater than $6.8 \mathrm{~mm}$ ), preorbital and postorbital processes poorly developed, third molar present (Handley 1991). 


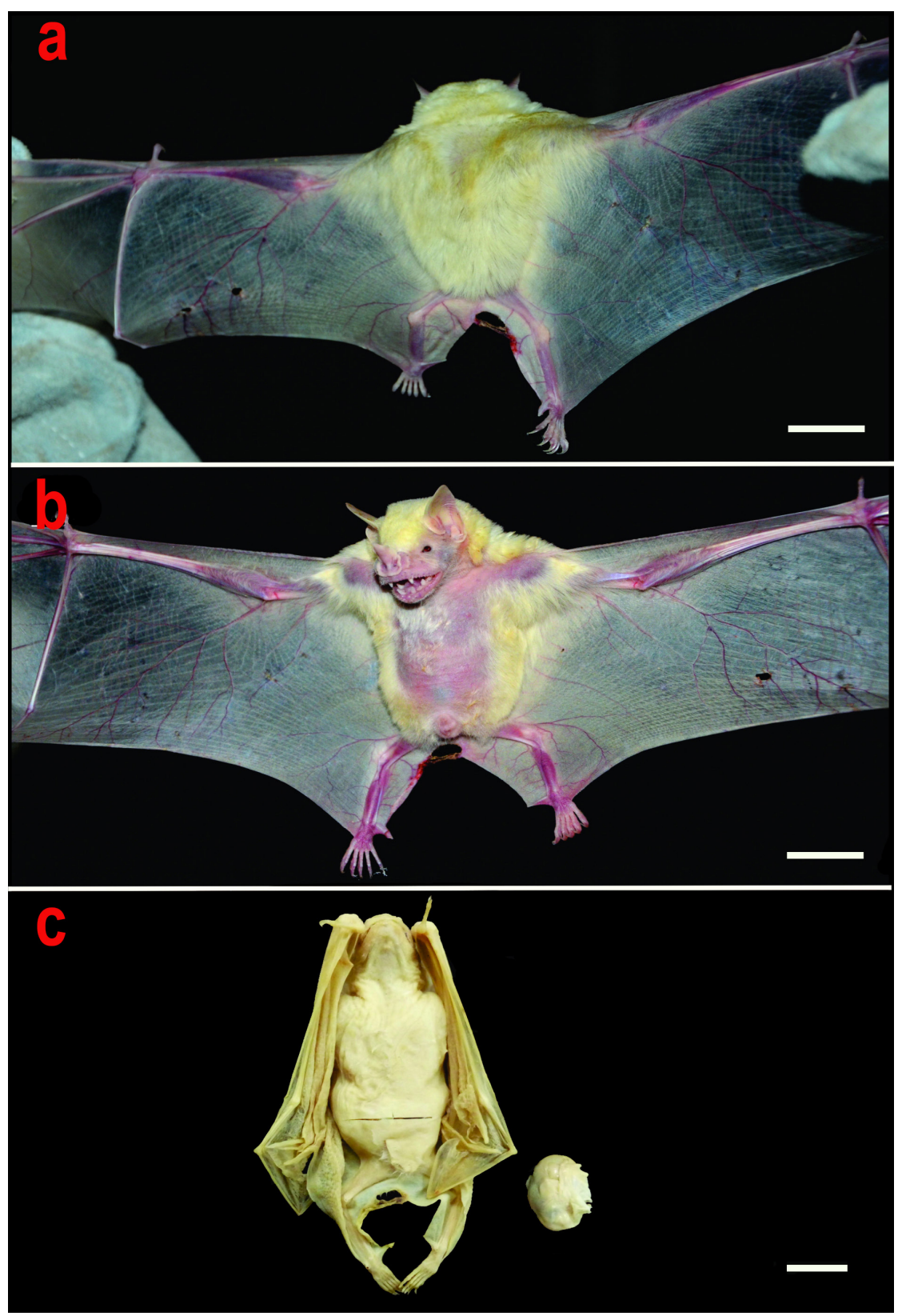

Figure 1. Pregnant albino specimen of Artibeus planirostris ( + UFPE 3709) captured in Paraíba, Brazil: dorsal (a) and frontal (b) perspectives, and the specimen with its male fetus on the right side (c). Bars $=2 \mathrm{~cm}$.

All external morphological measures (Lengh in $\mathrm{mm}$ : head-body=79.3, ear=20.1, forearm=57.6, thumb=9.7, third metacarpal=52.8, fourth metacarpal=51.3, fifth metacarpal=54) are in accordance with the descriptions of this species by Hollis (2005). The specimen presented alopecia in shoulders, thorax, and abdomen (Figure 1).

In Brazil, nine species of albino bats have been recorded. Here we report the 16th individual with this genetic disorder and the second case for A. planirostris in the country. This is the first study to deposit an albino specimen of this species in a scientific collection (Table I).

Cases of albinism in Brazil have been reported for all biomes except the Pantanal. This is the third record of an albino bat in Caatinga. The number of albino bats recording in this biome is similar to that observed for Cerrado, Amazonian, and the Atlantic Forest (Figure 2). 
Table I. Species, localities, sex and ages of the albino bats recorded in Brazil. Codes refer to numbers indicated in Figure 2. $\mathrm{N}=$ number of individuals, $\mathrm{A}=\mathrm{adult}$, and $\mathrm{Y}=$ young.

\begin{tabular}{|c|c|c|c|c|}
\hline Species & Municipality/state & Code & N (sex/age) & References \\
\hline \multirow{2}{*}{$\begin{array}{l}\text { Artibeus planirostris } \\
\qquad \text { (Spix, 1823) }\end{array}$} & $\begin{array}{c}\text { Fortaleza/ } \\
\text { Ceará }\end{array}$ & 1 & $\begin{array}{c}1 \text { (lost } \\
\text { specimen) }\end{array}$ & Uieda (2000) \\
\hline & $\begin{array}{l}\text { Santa Terezinha/ } \\
\text { Paraíba }\end{array}$ & 2 & $1(\mathrm{O} / \mathrm{A})$ & Present Study \\
\hline \multirow{2}{*}{$\begin{array}{l}\text { Carollia perspicillata } \\
\quad \text { (Linnaeus, 1758) }\end{array}$} & $\begin{array}{c}\text { Igaporã/ } \\
\text { Bahia }\end{array}$ & 3 & $1(P / A)$ & Falcão (2014) \\
\hline & $\begin{array}{l}\text { Porto Velho/ } \\
\text { Rondônia }\end{array}$ & 4 & $1(\hat{\partial} / Y)$ & Rosa et al. (2017) \\
\hline $\begin{array}{c}\text { Dermanura cinerea } \\
\text { (Gervais, 1856) }\end{array}$ & $\begin{array}{l}\text { Planaltina/ } \\
\text { Goiás }\end{array}$ & 5 & $1(\hat{O} / A)$ & Oliveira \& Aguiar (2008) \\
\hline \multirow{3}{*}{$\begin{array}{c}\text { Desmodus rotundus } \\
\text { (É. Geoffroy, } \\
\text { 1810) }\end{array}$} & Apiaí/São Paulo & 6 & $1(\% / Y)$ & Uieda (2001) \\
\hline & Almenara/ Minas Gerais & 7 & 2 (ふ/A both) & Moreira et al. (1992) \\
\hline & Rio Branco do Sul/ Paraná & 8 & $1(\hat{\delta} / A)$ & Guimarães et al. (2013) \\
\hline $\begin{array}{l}\text { Diaemus youngi } \\
\text { (Jentink, 1893) }\end{array}$ & Pacajá/Pará & 9 & $1(-/-)$ & Uieda (2015) \\
\hline $\begin{array}{l}\text { Eumops glaucinus } \\
\text { (Wagner, 1843) }\end{array}$ & $\begin{array}{l}\text { Campinas/ } \\
\text { São Paulo }\end{array}$ & 10 & $1(\widehat{\jmath} / Y)$ & Sodré et al. (2004) \\
\hline $\begin{array}{c}\text { Gradenycteris crenulatum } \\
\text { (Geoffroy, 1803) }\end{array}$ & $\begin{array}{l}\text { Barra do Ouro/ } \\
\text { Tocantins }\end{array}$ & 11 & $1(\widehat{\jmath} / A)$ & Zórtea \& Silva (2017) \\
\hline \multirow{2}{*}{$\begin{array}{l}\text { Molossus molossus } \\
\quad(\text { Pallas, 1766) }\end{array}$} & $\begin{array}{l}\text { Imperatriz/ } \\
\text { Maranhão }\end{array}$ & 12 & $1(+/ A)$ & Nascimento et al. (2018) \\
\hline & $\begin{array}{l}\text { Santa Vitória do Palmar/Rio } \\
\text { Grande do Sul }\end{array}$ & 13 & $1(P / A)$ & Veiga \& Oliveira (1995) \\
\hline \multirow{2}{*}{$\begin{array}{l}\text { Peropteryx } \\
\text { kappleri } \\
\text { Peters, } 1867\end{array}$} & Parauapebas/ Pará & 14 & $1(\hat{\partial} / A)$ & Bernardi et al. (2019) \\
\hline & Canaã dos Carajás/ Pará & 15 & $1(-/ Y)$ & Bernardi et al. (2019) \\
\hline
\end{tabular}

Here we report an adult female and pregnant albino bat. The adult condition has been reported in $62.6 \%$ of the albino bats captured in Brazil (Table I). Albino bat pregnancies are reported for other bat species, such as Myotis lucifugus (Brigham \& James 1993) and Desmodus rotundus (Sánchez-Hernández et al. 2010). Thus, it is possible that albinism does not affect bat survival and reproduction.
Considering that albinism is a rare hypopigmentary disorder, we emphasize the importance of researchers to record the cases found in nature. These data contribute to increase the knowledge of this phenomenon. We also reinforce the importance of albino specimens deposited in museums as a source of biological knowledge. 


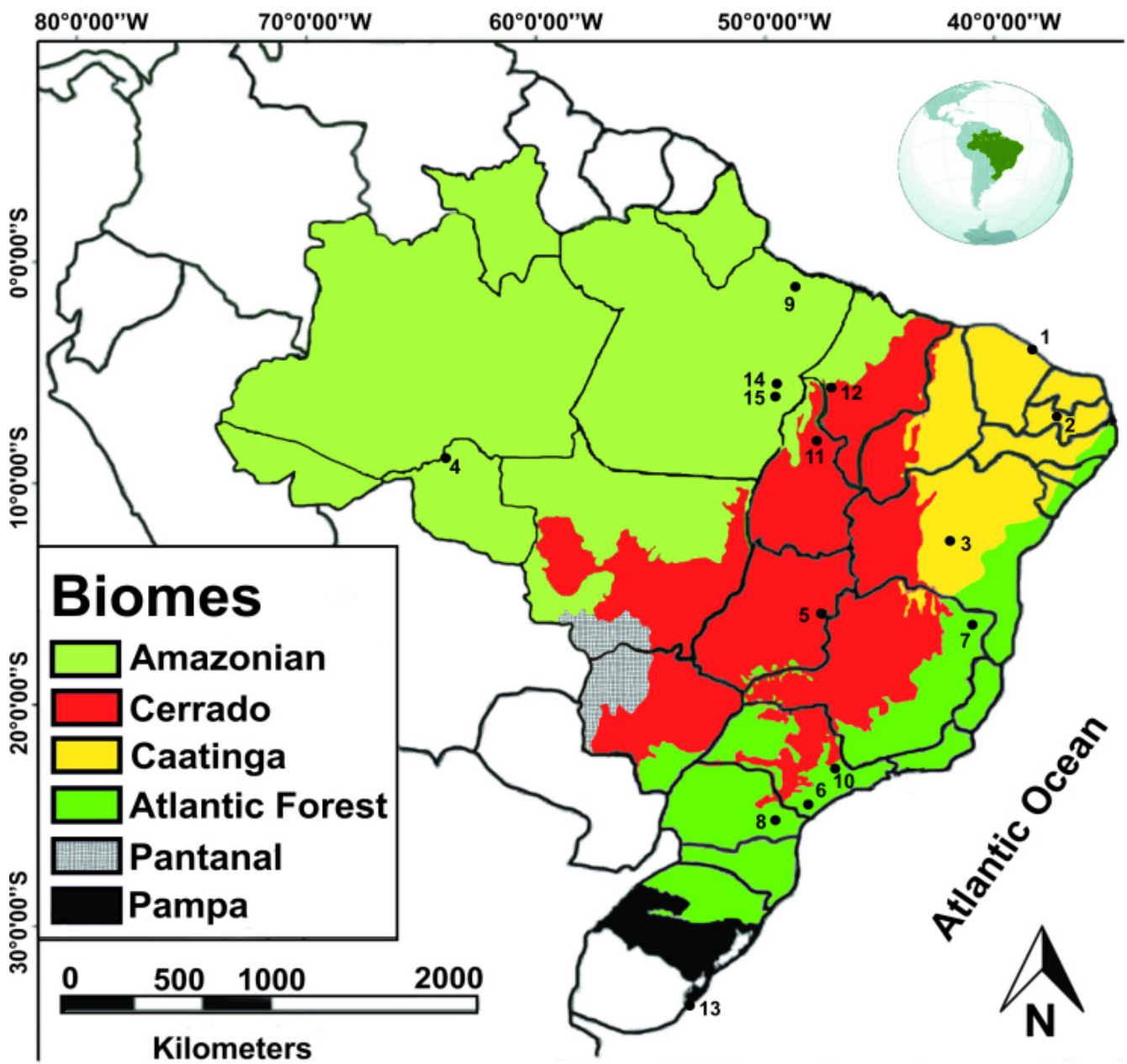

Figure 2. Partial map of South America showing Brazilian biomes. Circles indicate locations where albino bats have been recorded. The numbers refer to the codes in Table I.

\section{REFERENCES}

BERNARDI LFO, PROUS X, RIBEIRO MS, MASCARENHAS J, GENELHÚ SMC, SIMÕES MH \& BEZERRA T. 2019. First record of albinism for the doglike bat, Peropteryx kappleri Peters, 1867 (Chiroptera, Emballonuridae). Subterr Biol 30: 33-40.

BRIGHAM RM \& JAMES AK. 1993 A true albino little brown bat, Myotis lucifugus, from Saskatchewan. Blue Jay 51: 213-214.

FALCÃO FC. 2014. First record of complete albinism in Carollia perspicillata (Chiroptera: Phyllostomidae). Chiroptera Neotropical 20: 1234-1236.

GUIMARÃES M, SATO T, KAKU-OLIVEIRA N \& UIEDA W. 2013 New case of complete albinism in Desmodus rotundus (Phyllostomidae: Desmodontinae) from Southern Brazil. 16th International Bat Research Conference and 43rd Annual Meeting of the North American Society for Bat Research, San Jose, Costa Rica.
HANDLEY CO. 1991. The identity of Phyllostoma planirostre Spix, 1823 (Chiroptera: Stenodermatinae). Bull Am Mus Nat Hist Alternative 206: 12-17.

HOFREITER M \& SCHONEBERG T. 2010. The genetic and evolutionary basis of colour variation in vertebrates. Cell Mol Life Sci 67: 2591-2603.

HOLLIS L. 2005. Artibeus planirostris. Mamm Species 775: 1-6.

LUCATI F \& LÓPEZ-BAUCÉLLS A. 2016. Chromatic disorders in bats: a review of pigmentation anomalies and the misuse of terms to describe them. Mamm Rev 47: 1-13.

MOREIRA EC, SILVA MCP \& VELOSO JG. 1992. Albinism em Desmodus rotundus rotundus Chiroptera (E. Geoffroy, 1810). Arq Bras Med Vet Zootec 44: 549-552.

NASCIMENTO ACS, DOURADO ACM, TREVELIN LC \& BEZERRA AMR. 2018. First record of total albinism in Molossus molossus (Chiroptera: Molossidae) from Northeastern Brazil. Bol Mus Para Emilio Goeldi Ciênc Nat 13: 273-277. 
NEVES RML, TELINO-JÚNIOR WR \& NASCIMENTO JLX. 1999. Aves da Fazenda Tamanduá, Santa Terezinha, Paraíba. Recife: Editora Universitária UFPE, 54 p.

OLIVEIRA HFM \& AGUIAR LMS. 2008. A new case of complete albinism in bat from Brazil. Chiroptera Neotropical 14: 421-423.

PACHECO SM. 2004. Técnicas de campo empregadas no estudo de quirópteros. Caderno La Salle XI 1: 193-205.

ROSA AR, MARTORELLI LFA, ALMEIDA MF \& AIRES CC. 2017. Albinim in Carollia perspicillata (Chiroptera; Phyllostomidae), in the state of Rondônia, Brazil. A brief review of albinism in bats. Biotemas 30: 71-77.

SÁNCHEZ-HERNÁNDEZ C, ROMERO-ALMARAZ MDL, TABOADASALGADO A, ALMAZÁN-CATALÁN A, SCHNELL GD \& SÁNCHEZVAZQUEZ L. 2010 Five albino bats from Guerrero and Colima, Mexico. Chiroptera Neotropical 16: 522-527.

SODRÉ MM, UIEDA W \& BALDIM M. 2004. First record of albinism in the bat Eumops glacinus (Molossidae) from Southeastern Brazil. Chiroptera Neotropical 10: 200-201.

UIEDA W. 2000. A review of complete albinism in bats with five new cases from Brazil. Acta Chiropterol 2: 97-105.

UIEDA W. 2001. Behavior of an albino vampire bat, Desmodus rotundus (E. Geoffroy) (Chiroptera, Phyllostomidae), in captivity. Rev Bras Zool 18: 641-644.

UIEDA W. 2015. Morcego vampiro albino é encontrado em Pacajá, sudoeste do Pará. Available at: <http://g1.globo. com/pa/para/noticia/2015/09/morcego-vampiroalbino-e-encontrado-em-pacaja-no-sudoeste-do-para. html $>$ Accessed on 2019-11-25.

VEIGA LA \& OLIVEIRA AT. 1995. Um caso de albinismo completo em morcego Molossus molossus, Pallas (Chiroptera: Molossidae) em Santa Vitória do Palmar, RS, Brasil. Braz Arch of Biol Techn 38: 879-881.

VIZOTTO LD \& TADDEI VA. 1973. Chave para determinação de quirópteros brasileiros. São José do Rio Preto: Universidade Estadual de Paulista, 72 p.

ZORTÉA M \& SILVA MC. 2017. Albinism in the striped spearnosed bat Gardnerycteris crenulatum (Chiroptera: Phyllostomidae) with an updated list of albino bats in the World. Mammalia 82: 78-84.

\section{How to cite}

LEAL ESB, LIRA TC, GARCIA ACL \& MONTES MA. 2021. Albinism in Artibeus planirostris (Chiroptera, Phyllostomidae) in the Caatinga biome and updated list of albino bats in Brazil. An Acad Bras Cienc 93: e20200582. DOI 10.1590/0001-3765202120200582.

Manuscript received on April 18, 2020;

accepted for publication on November 6, 2020

\section{EDSON S.B. LEAL ${ }^{1}$}

https://orcid.org/0000-0002-6577-2330

THAÍS C. LIRA ${ }^{2}$

https://orcid.org/0000-0001-8143-9485

\section{ANA C.L. GARCIA ${ }^{3}$}

https://orcid.org/0000-0001-8352-6080

\section{MARTÍN A. MONTES 4}

https://orcid.org/0000-0002-9051-0287

'Universidade Federal de Pernambuco, Departamento de Zoologia, Av. Prof. Moraes Rêgo, 1235, 55608-680 Recife, PE, Brazil

${ }^{2}$ Instituto Fazenda Tamanduá, Km 12, BR 361, 58720-000 Santa Terezinha, PB, Brazil

${ }^{3}$ Universidade Federal de Pernambuco, Centro Acadêmico de Vitória, Rua Alto do Reservatório, s/n, 55608-680 Vitória de Santo Antão, PE, Brazil

${ }^{4}$ Universidade Federal Rural de Pernambuco, Departamento de Biologia, Rua Dom Manoel de Medeiros, s/n, 52171-90 Recife, PE, Brazil

Correspondence to: Ana Cristina Lauer Garcia E-mail:anacristina.garcia@ufpe.br

\section{Author contribution}

Edson Silva Barbosa Leal and Thaís de Castro Lira collected the albino bat. Edson Silva Barbosa Leal and Martín Alejandro Montes identified the albino bat. Ana Cristina Lauer Garcia, Martín Alejandro Montes and Edson Silva Barbosa Leal wrote the manuscript.

(c) BY 